\title{
Behavioral Analysis of Thermoelectric Module under Different Configurations and Temperature Gradient
}

\author{
(Analisis Kelakuan Modul Termaelektrik di Bawah Konfigurasi dan Kecerunan Suhu yang Berbeza) \\ R. Mohamed, A. M. Yusop*, A. Mohamed \& N. I. Nordin
}

\begin{abstract}
This study analyzes the behavior of the thermoelectric module (TEM) in a transient status which allows natural cooling condition. The analysis mainly aims to extract energy from the ordinary heat source and convert it into useful electrical power. Several TEM configurations which involve single TEM and multi stage TEM are manipulated within the system since the previous studies only focused on single TEM behavior only. For a complete TEM behavioral analysis results, the performance of multistage TEM must be taken into account as this type of configurations is usually used in highend TEM application to produce greater voltage value. A multistage TEM that is connected electrically in series and thermally in parallel produces a higher generated voltage value compared to a single TEM. TEM temperature gradients also are changed throughout the experiment to examine how this term affects the TEM behavior. The results show that the multistage TEM contributes the highest output voltage and it depends on the number of cascaded TEM. Furthermore, a higher temperature gradient contributes to more voltage generated by the TEM. TEM analysis with heatsink is proved to have larger temperature gradient to maintain the cold side of the TEM junction. Loading effect analysis shows that the TEM system can obtain 5 V of stable voltage when the load resistor connected to the system output is $200 \Omega$ and above.
\end{abstract}

Keywords: Thermoelectric; temperature gradient; heat sink

ABSTRAK

Kajian ini menganalisis tingkah laku modul termoelektrik (MTE) dalam keadaan fana yang membolehkan keadaan penyejukan semula jadi berlaku. Tujuan utama analisis ini adalah untuk mendapatkan tenaga daripada sumber haba biasa dan menukarkannya kepada tenaga elektrik yang berguna. Beberapa konfigurasi MTE yang melibatkan MTE tunggal dan MTE berbilang dimanipulasikan dalam sistem ini yang mana kajian sebelum ini hanya tertumpu kepada tingkah laku MTE tunggal sahaja. Untuk keputusan analisis tingkah laku MTE yang lengkap, prestasi MTE berbilang perlu diambil kira di mana konfigurasi jenis ini biasanya digunakan dalam aplikasi MTE tingkat tinggi bagi menghasilkan nilai voltan keluaran yang lebih besar. MTE berbilang yang disambungkan secara elektrik sesiri dan haba selari menghasilkan nilai voltan keluaran yang lebih tinggi berbanding MTE tunggal. Kecerunan suhu MTE juga berubah di sepanjang ujikaji ini dijalankan bagi mengkaji bagaimana ia mempengaruhi tingkah laku MTE. Keputusan menunjukkan bahawa MTE berbilang menyumbang kepada nilai voltan keluaran tertinggi dan ia bergantung kepada jumlah MTE yang dilatakan. Tambahan pula, kecerunan suhu yang lebih tinggi menjurus kepada pertambahan nilai voltan yang dihasilkan oleh MTE ini. Analisis MTE dengan penenggelam haba telah dibuktikan mempunyai kecerunan suhu yang lebih besar untuk mengekalkan bahagian sisi sejuk MTE ini. Analisis kesan pergantungan kepada beban menunjukkan bahawa sistem MTE ini boleh mencapai 5 V voltan stabil apabila perintang beban yang disambungkan kepada keluaran sistem adalah $200 \Omega$ dan ke atas.

Kata kunci: Termoelektrik; kecerunan suhu; penenggelam haba

\section{INTRODUCTION}

Renewable energy is in high demand today as pollution and global warming are encountered worldwide. Renewable energy produced from natural sources, such as heat (Bonin et al. 2013; He et al. 2012; Kim 2013), wind (Hong \& Chen 2014; Tianpei \& Wei 2014), and vibration (Bandyopadhyay \& Chandrakasan 2012), are commonly used by those expecting to achieve environmentally green energy sources. Most electricity is generated at power stations by generators, the operations of which sometimes involve high chemical effects, such as nuclear fission or chemical combustion. Such electricity generation method has exacerbated global pollution. Nonetheless, the search for smarter electricity generation solutions using wasted 
energy has begun worldwide; zero wasted energy is also a target to improve energy cycles consistently. Thus, many studies have been performed on ways to convert wasted energy, such as mechanical energy, sound energy, and heat energy, into electricity. This option is considered to achieve better electricity generation methods by using wasted energies instead of eliminating them. This process is more commonly called energy harvesting, the applications of which have been studied widely.

Heat energy is one of the most frequently produced types of wasted energy in the entire application system. Therefore, efforts to convert this particular wasted energy into electricity are seriously considered as world demands are reached (Saadatfar et al. 2013). Heat energy can be easily found in applications that govern potential and kinetic energies, whose sources are widely and easily available. For example, heat energy can be obtained from heat produced by the exhaust and engine of automobiles (He et al. 2013; Stevens et al. 2014), by mobile phones (Aminov \& Agrawal 2014) and power plants (Merschmann et al. 2013; Rafiee et al. 2012), as well as from the natural temperature of surroundings, such as solar temperature (Liao et al. 2014; Zhang et al. 2014). Such wasted heat energies can be converted into electricity. The temperature gradient between hot and cold sides is important to convert heat energy into an electric generator that should be utilized. In Ref. (Carmo et al. 2011), the relationship between temperature gradient and the amount of electricity generated has been examined. The result shows that the open circuit voltage of an energy harvester increases when the temperature gradient of the harvester rises.

Wasted heat energy is converted into electricity through a thermoelectric module (TEM) or a thermoelectric generator. Both of these devices can directly convert heat energy by the thermal gradient absorbed at the junction that is turned into electricity. A temperature gradient or temperature difference of heat energy should exist across the device to convert heat energy into electricity using TEM (Attia 2014). Accordingly, cold and hot sides should exist at the TEM junction to convert heat energy into electricity using the device. A charge carrier sufficiently diffuses the temperature gradient from the hot side to the cold side of the TEM for the device to generate electricity. TEM applications are increasingly becoming popular because the device is widely applicable, from extremely high temperatures, such as heat from generators or automobiles, to moderate temperatures, such as human body temperature through watches and electronic medical instruments. TEM is generally a low-efficiency device (Weng \& Huang 2014). TEM is used by applications that consider reliability and costs, such as industrial steam condensers (Bomberger et al. 2013). Adopting TEM is also considered in remote areas and in the ocean, where passive temperature occurs. Given that TEM devices produce very low amounts of voltage, ways to control the system using a controller to create electricity in preferable amounts have been investigated (Bomberger et al. 2013).

Two conditions occur in MTE is static and dynamic. The static condition is when TEM is controlled by other devices to dissipate heat energy from the hot side to the cold side of the device. The common device used in this case is known as a heatsink. Many researchers have focused on modeling thermoelectricity for cooling purposes, which involve heatsinks (Ma\&Yu 2014; Meng et al. 2013; Wang et al. 2013). TEM modeling for heating has been insufficiently studied in the past few years, such as in Refs. (He et al. 2013; Rabari et al. 2014). Moreover, a heatsink is not used in dynamic conditions to allow the cold side to cool naturally. However, this part is seldom discussed because of the complexity of the mathematical equation that requires a solution (Nguyen \& Pochiraju 2013). In Ref. (Nguyen \& Pochiraju 2013), the authors completely modeled a TEM for transient analysis but without comparing with TEM that uses a heatsink.

The other purpose of harvesting energy from wasted energy is to reuse generated energy back to the original application or to other applications. Most regenerated energy is used by applying the produced wasted energy itself. This study investigates the amount of electrical energy generated by TEM, which is a behavior explained extensively. This work also shows how the heatsink affects TEM behavior, which has not been analyzed by previous researchers yet.

\section{PHYSICAL MODEL AND MEASUREMENT SETUP}

The process flow of TEM applications from the input temperature is shown in Figure 1. The TEM block system has two main inputs: hot-side and cold-side temperatures. Both temperatures affect TEM performance. The harvested output voltage of TEM with different configurations and circumstances is measured and analyzed to generate a concrete conclusion on the TEM behavior in dynamic condition. The following block diagram as shown in Figure 1 shows the connection between harvested voltages from a TEM TEP1-12656-0.6 (Thermonamics) with a maximum power point control (MPPC) board and a $2.5 \mathrm{~V}$ supercapacitor $(10 \mathrm{~F})$. The specifications of the TEM used in this design are listed in Table 1.

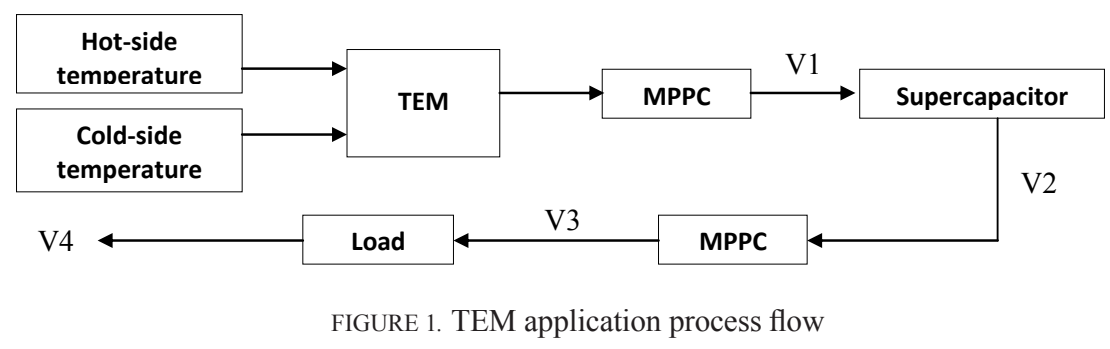


Two MPPC boards (DC 1587) from Linear Technology are used in this analysis: the first one is used to mainly track the maximum voltage, and the other is used to stabilize the output voltage from the supercapacitor before the voltage is loaded. The supercapacitor functions as an energy storage device and has been boosted from the first MPPC. The test point voltage is also labeled in the same figure.

TABLE 1. Specification of TEM (TEP1-12656-0.6)

\begin{tabular}{lc}
\multicolumn{1}{c}{ Specifications } & Values \\
\hline Hot side temperature $\left({ }^{\circ} \mathrm{C}\right)$ & 300 \\
Cold side temperature $\left({ }^{\circ} \mathrm{C}\right)$ & 30 \\
Open circuit voltage $(\mathrm{V})$ & 8.4 \\
Matched load resistance $(\Omega)$ & 1.2 \\
Matched load output voltage $(\mathrm{V})$ & 4.2 \\
Matched load output current $(\mathrm{A})$ & 3.4 \\
Matched load output power $(\mathrm{W})$ & 14.6 \\
Heat flow across the module $(\mathrm{W})$ & $\approx 365$ \\
Heat flow density $\left(\mathrm{W} \mathrm{cm}^{-2}\right)$ & $\approx 11.6$ \\
AC resistance measured at $27^{\circ} \mathrm{C}$ and $1000 \mathrm{~Hz}(\Omega)$ & $0.5-0.7$ \\
\hline
\end{tabular}

An experiment is then performed using several apparatus setups in the laboratory based on the process flow in Figure 2. The other apparatuses used in the experimental setup are a hot plate from Stuart, a temperature data logger from PicoLog, a data acquisition card (NI-USB 6211) from National Instrument, and a thermocouple. This entire device is attached to the TEM to record the temperature value at both TEM sides using thermocouples and send the harvested voltage value to a computer with the MATLAB environment applied. The hot plate is used as a heat source. The hot side of the TEM is placed on top of the hot plate for direct contact. This hot plate can supply heat of up to $400^{\circ} \mathrm{C}$. The hot plate temperature used in this experiment is limited to only $150^{\circ} \mathrm{C}$. The data logger used has a total of 8 channels that can be connected to the thermocouples to record the TEM temperature value. The voltage data from the data acquisition card are recorded every second and are limited to $700 \mathrm{~s}$. A heatsink is only added to the environment where the analysis is in steady state.

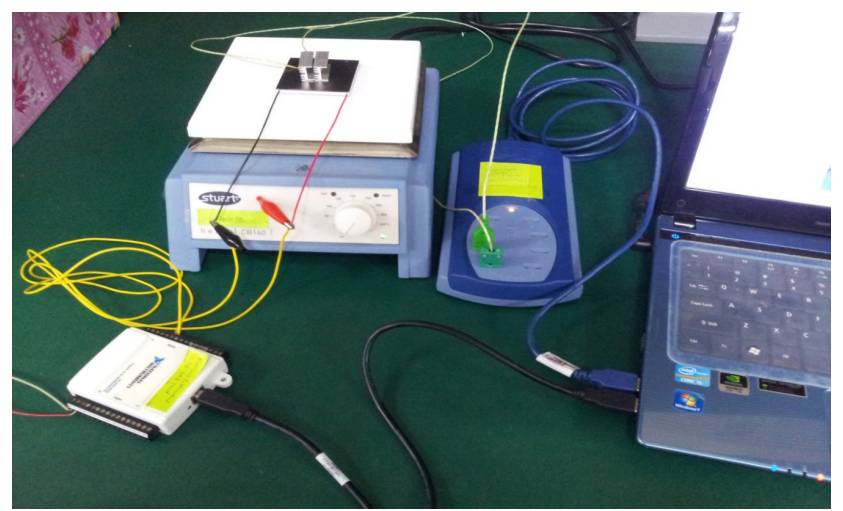

FIGURE 2. Experimental setup in the laboratory
The overall TEM analysis is divided into four parts. The first part is analyzing the TEM voltage behavior harvested with different hot-plate temperature values, the second part analyzes the TEM behavior under different numbers of TEM, the third part continues the analysis in part two but with a heatsink, and the last part is the loading effect analysis. The analyses are conducted to mainly obtain the best TEM configuration with the optimum operating temperature that this TEM can uphold. This part is the most important and it requires clarification before any MPPT scheme is added. The analysis starts by harvesting the voltage from the hot plate using the TEM. The TEM is placed directly on top of the hot plate, while two thermocouples are placed on both TEM sides to measure the surface temperature. Parts 1 to 3 are analyzed in an open circuit condition without any load connected to the system, whereas the last part is performed in a closed circuit. The capability of the TEM to generate voltage with different conditions is a key focus because the harvested voltage from this device is extremely small. For multistage TEM, the TEM is connected electrically in series and thermally in parallel, as shown by the built diagram in Figure 3. The TEM consists of several consecutive TEMs numbered from 1 to $n$, where Tih and Tic are the hot-side and cold-side temperatures at the $i$-th TEM module $(1 \leq i \leq$ $n)$, respectively.

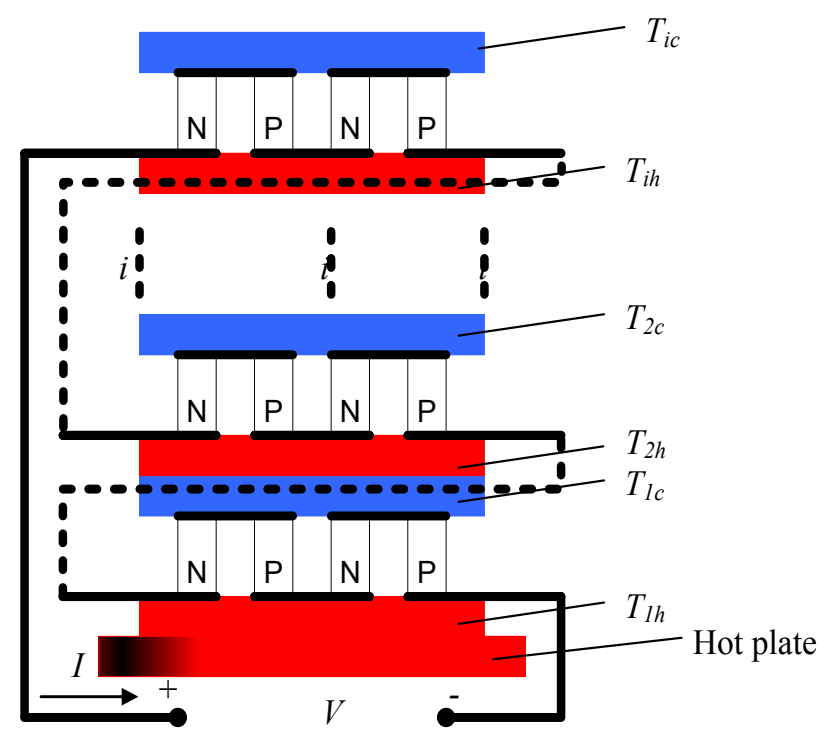

FIGURE 3. Multistage TEM configuration

\section{EXPERIMENTAL RESULTS}

The measurement is based on the analysis requirements for each part. The experiment has four parts, starting with the measurement of the harvested voltage from the TEM when the hot-plate temperature changes. The TEM configuration is then changed from single TEM to different numbers of cascaded TEM. The effect of the heatsink in the voltage generation of the TEM is further discussed in the third part, and the analysis ends in measuring the loading effect. 
HOTPLATE TEMPERATURE

For the first part of the experiment, the TEM is supplied with three different heat source temperatures: 50, 100, and $150^{\circ} \mathrm{C}$. The TEM involved in this analysis has three different configurations: single, three cascaded, and six cascaded. In this setup, "cascade TEM" means that the TEM is connected electrically in series and thermally in parallel. The experiment is started by setting the hot-plate temperature to $50^{\circ} \mathrm{C}$ within 700 seconds; the TEM voltage is harvested, and the temperatures of the hot and cold sides are then recorded. After 700 seconds, the experiment is continued by tuning the hot plate to the next testing temperature of $100^{\circ} \mathrm{C}$, followed by $150^{\circ} \mathrm{C}$. Figure 4 shows the analysis results for each TEM configuration.

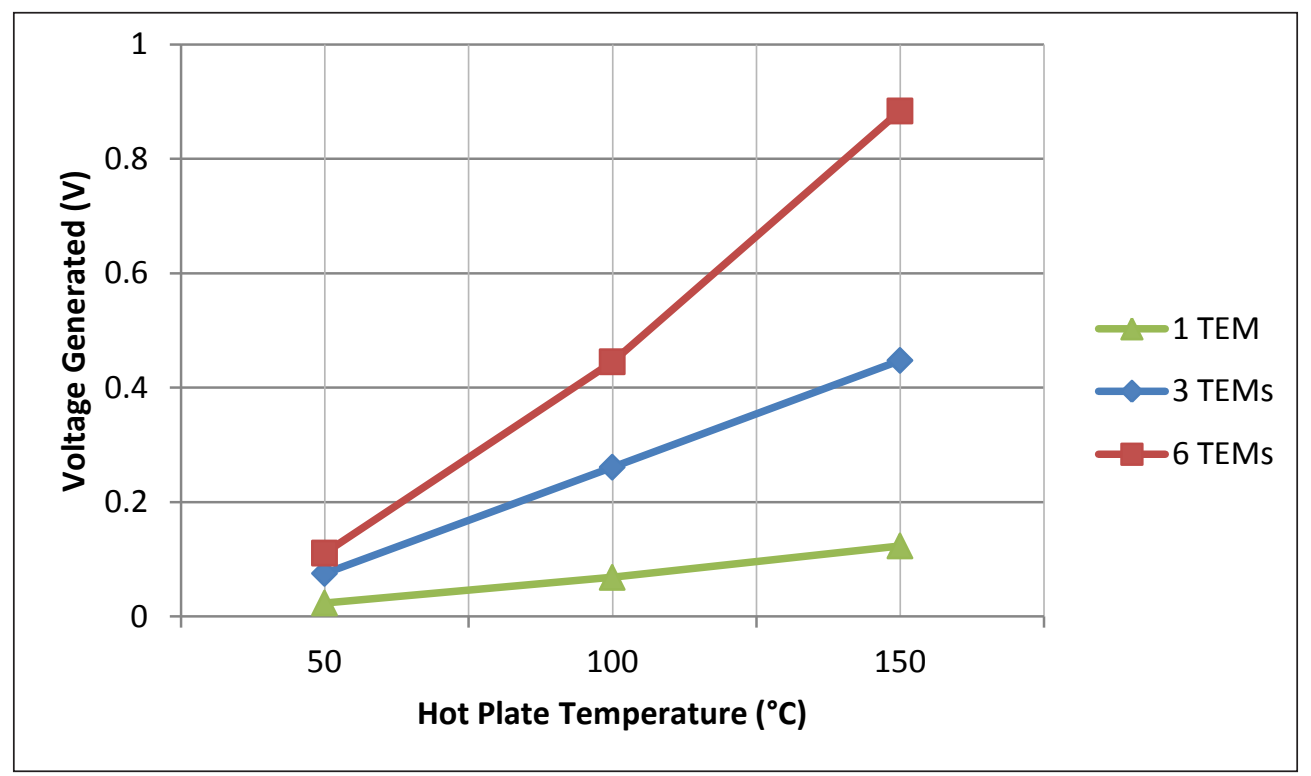

FIGURE 4. Voltage generated by the TEM with different heat source temperatures

The result shows that for each configuration, the voltage output outcomes increase when the hot-plate temperature rises. The output voltage for the entire configuration increases because the TEM hot-side temperature increases as the temperature gradient rises. Theoretically, the voltage generated by the TEM is augmented if the temperature gradient that exists between the cold-side and the hot-side junction is large. The plotted graph also shows that the harvested voltage value from the TEM relies on the number of TEMs. In the case between the three-cascaded TEM and six-cascaded TEM, the TEM voltage value is also doubled when the number of TEMs is doubled. This phenomenon is evident at all test points of the hot-plate temperature. This finding indicates that the TEM configuration can be changed by increasing the number of TEMs connected electrically in series and thermally in parallel when obtaining a higher harvested voltage value because the pre-stated TEM value is extremely small.

TEM CONFIGURATION

This experiment aims to investigate the output voltage value generated by the TEM in different configurations but with the same heat source temperature provided to the hot side of the TEM. Theoretically, if the TEM is cascaded, then the voltage generated by the TEM is multiplied by the value of the TEM connected. The following equation mathematically represents this theory:

$$
V_{\text {generated }, i}=i \times V_{\text {generated }}
$$

where $i$ is the number of cascaded TEM. A comparison is made for each configuration required by taking the results of the previous experiment. Table 2 shows the comparison of the experiment results for each TEM configuration with the same heat source temperature but with different numbers of TEMs.

TABLE 2. Voltage generated by TEM(s) with different numbers of TEM(s) with the same test temperature

\begin{tabular}{cccc}
\hline & \multicolumn{3}{c}{ Hot Plate Temperature } \\
\hline & $50^{\circ} \mathrm{C}$ & $100^{\circ} \mathrm{C}$ & $150^{\circ} \mathrm{C}$ \\
Number of TEM(s) & \multicolumn{3}{c}{ Mean Voltage Generated (V) } \\
1 & 0.0238 & 0.0685 & 0.1235 \\
3 & 0.0755 & 0.2611 & 0.4477 \\
6 & 0.111 & 0.4453 & 0.8836 \\
\hline
\end{tabular}

Figure 5 shows that the voltage generated by the $\operatorname{TEM}(\mathrm{s})$ increases in accordance with the increase in the total number of TEMs connected. For example, the output voltage value at $50^{\circ} \mathrm{C}$ is 0.0238 for a single TEM. Therefore, the output voltage value produced is the output voltage value of 0.0238 that is thrice that of the single TEM, which 
would generate 0.0714 . Evidently, the output voltage of the 3 TEMs at $50^{\circ} \mathrm{C}$ is 0.0755 , which is approximate to the expected value. The same condition is evident from the other two test temperatures. Nevertheless, the voltage value does not increase exactly as in theory. The reason for this lack of increase might be the drop in voltage inside the circuitry connection and the limited efficiency of TEM devices.

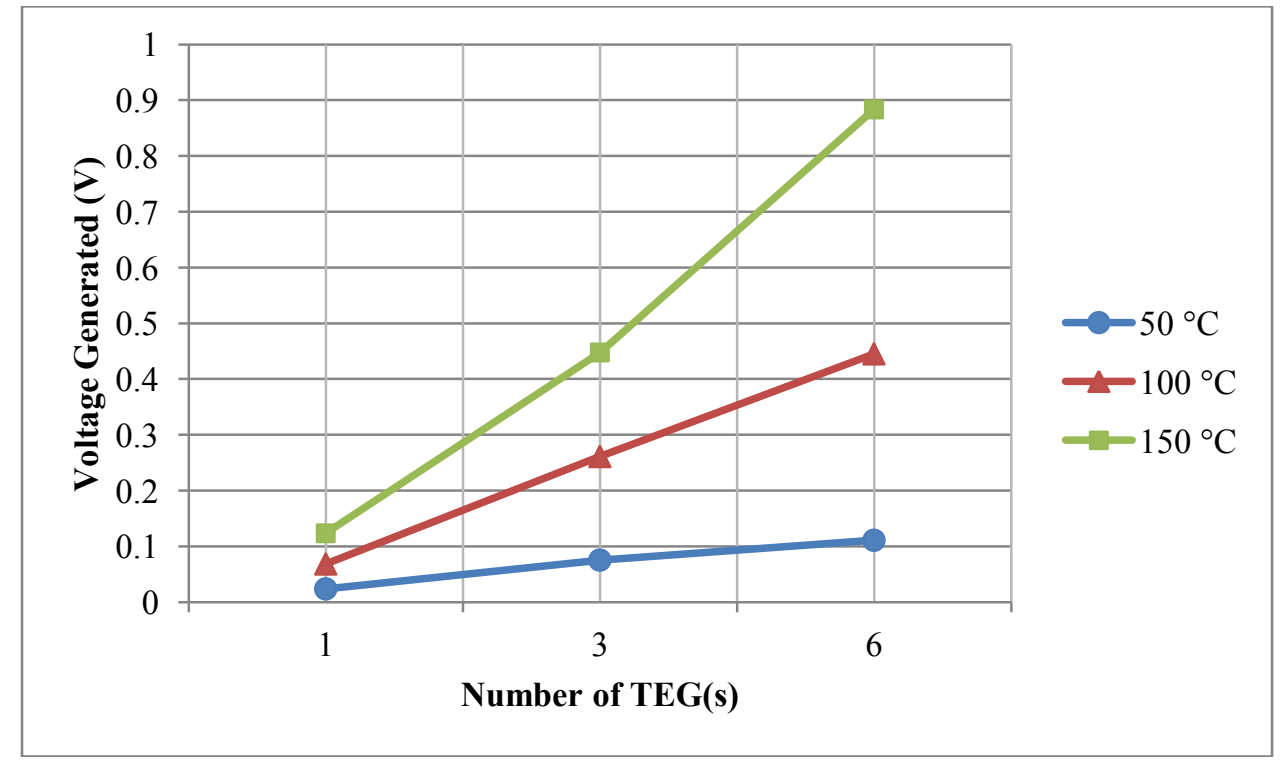

FIGURE 5. Voltage generated by TEM(s) with different numbers of TEM(s) with the same test temperature

TEM CONFIGURATION WITH A HEATSINK

The experiment in previous section is conducted again but this time with a heatsink. Five different heatsinks are used, the results of which are compared with that of the TEM without a heatsink. The specification of heatsink used in this analysis is listed in Table 3. The heatsink cools the cold side of the TEM by dissipating the heat of the TEM to the surroundings. Thus, the temperature of the cold side of the TEM would maintain approximately the same value throughout the experiment regardless of the temperature value of the hot side.

TABLE 3. Specifications of the heat sink used in the analysis

\begin{tabular}{|c|c|c|c|c|c|}
\hline Specification & Type A & Type B & Type C & Type D & Type E \\
\hline Length (mm) & 36.8 & 35 & 38.8 & 23 & 35 \\
\hline Width (mm) & 36.8 & 35 & 40.6 & 23 & 35 \\
\hline $\begin{array}{l}\text { Thermal } \\
\text { resistance }(\mathrm{C} / \mathrm{W})\end{array}$ & 4 & 23.4 & 7 & 23.4 & 15.3 \\
\hline Heatsink material & Aluminum & Aluminium & Aluminium & Aluminium & Aluminium \\
\hline Cooling package & $\begin{array}{c}\text { Ball Grid } \\
\text { Array } \\
\text { (BGA) }\end{array}$ & $\begin{array}{c}\text { Ball Grid } \\
\text { Array } \\
\text { (BGA) }\end{array}$ & $\begin{array}{c}\text { Ball Grid } \\
\text { Array } \\
\text { (BGA) }\end{array}$ & $\begin{array}{c}\text { Ball Grid } \\
\text { Array } \\
\text { (BGA) }\end{array}$ & $\begin{array}{c}\text { Ball Grid } \\
\text { Array } \\
\text { (BGA) }\end{array}$ \\
\hline
\end{tabular}

It is noticable from Table 3 that all the heatsink is used the same material and cooling package. The different between them can be seen from the heatsink size and the thermal resistance of the heatsink. It shows that Type B and Type $\mathrm{D}$ heatsink having the highest thermal resistance. Through this device, the heatsink tends to maintain the coldside temperature value although the hot-side temperature increases. According to Table 4, the cold-side temperature differences are $9.5,15.9,7,15.9$ and $6.3^{\circ} \mathrm{C}$ when the hotplate temperature is increased from $50^{\circ} \mathrm{C}$ to $150^{\circ} \mathrm{C}$ for each heatsink type. By contrast, the cold-side junction continuously increases as the hot-side temperature rises when no heatsink is used. When the hot-plate temperature is increased from $50^{\circ} \mathrm{C}$ to $150^{\circ} \mathrm{C}$, the temperature difference 
of the cold-side temperature is $24.13^{\circ} \mathrm{C}$, which is very high compared with that in the system with a heatsink. Although five different heatsinks are used, the cold-side temperature variation is within $6.3-15.9^{\circ} \mathrm{C}$ only. The experiment proves that the hot and cold sides of the TEM have a larger temperature gradient by using a heatsink rather than by natural cooling. Thus, this device is used on steady state analysis to maintain the cold-side temperature.

TABLE 4. Measurement of the cold-side temperature of six TEMs with and without a heatsink

\begin{tabular}{ccccccc}
\hline & $\begin{array}{c}\text { Without } \\
\text { heatsink }\end{array}$ & $\begin{array}{c}\text { With heat- } \\
\text { sink (Type } \\
\text { A) }\end{array}$ & $\begin{array}{c}\text { With heat- } \\
\text { sink (Type } \\
\text { B) }\end{array}$ & $\begin{array}{c}\text { With heat- } \\
\text { sink (Type } \\
\text { C) }\end{array}$ & $\begin{array}{c}\text { With heat- } \\
\text { sink (Type }\end{array}$ & $\begin{array}{c}\text { With heat- } \\
\text { sink (Type }\end{array}$ \\
\hline Hot-plate Temperature $\left({ }^{\circ} \mathrm{C}\right)$ & \multicolumn{7}{c}{ Cold-side Temperature, Tc $\left({ }^{\circ} \mathrm{C}\right)$} \\
50 & 29.05 & 28.9 & 31.4 & 30.8 & 31.4 & 31.4 \\
100 & 38.47 & 33.8 & 37.9 & 33.3 & 37.9 & 37.9 \\
150 & 53.18 & 38.4 & 47.3 & 37.8 & 47.3 & 47.3 \\
\hline
\end{tabular}

Figure 6 shows the comparison of the cold-side temperature graph for all the heatsinks used in this experiment together with the result without a heatsink. Evidently, the value of the cold-side temperature of the TEM with a heatsink at the cold junction is maintained in a very small range regardless of the hot-side temperature supplied. Thus, the heatsink contributes to the high temperature gradient. Meanwhile, the value of the coldside temperature of the TEM without a heatsink increases in a wide range as the hot-side temperature increases. Therefore, the temperature gradient becomes smaller for the TEM system without a heatsink compared with that with a heatsink.

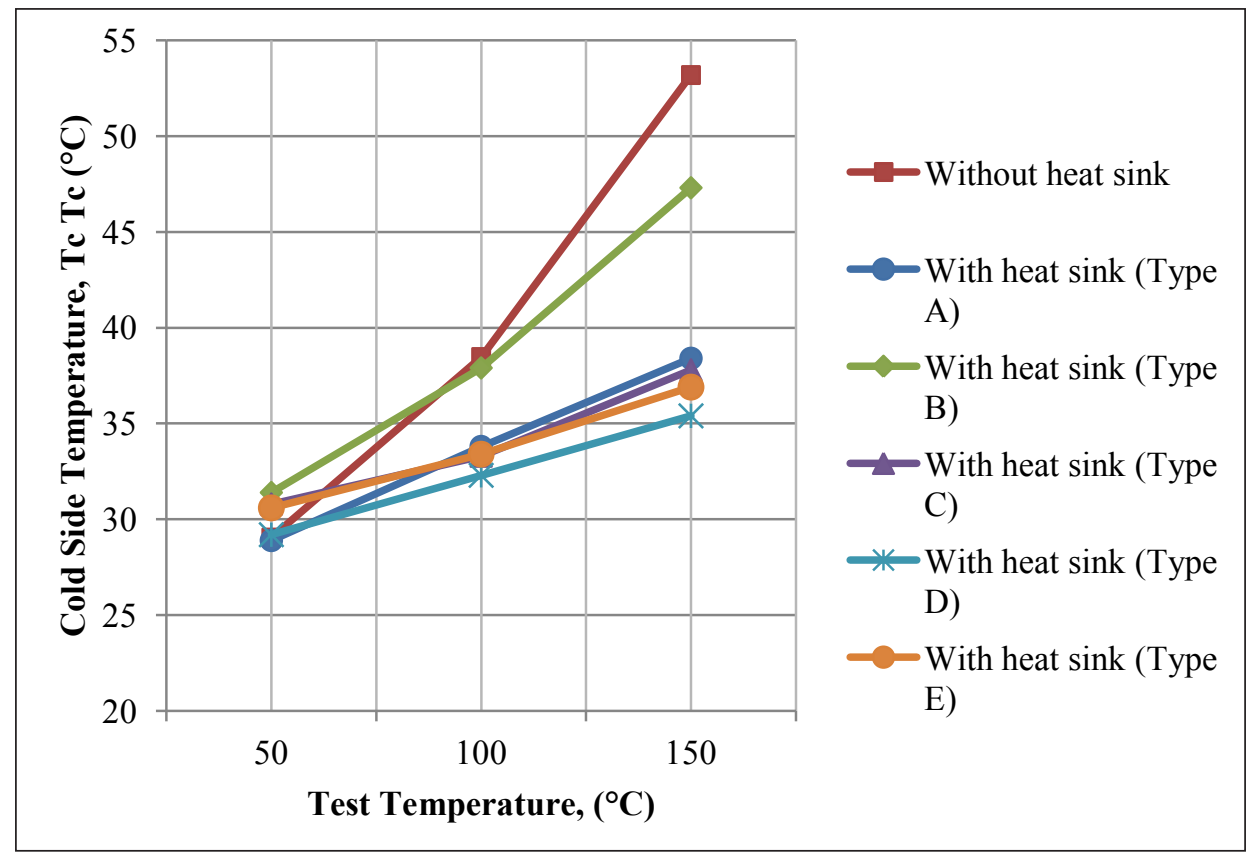

FIGURE 6. Measurement of the cold-side temperature of 6 TEMs with and without a heatsink

Next, the temperature gradient behavior with and without a heatsink is shown in Figure 7, where the temperature gradient of the TEM configuration without a heatsink appears much smaller than that of the TEM with a heatsink. The TEM manner of dissipating heat without a heatsink by cooling the natural environment is different for each state. This situation is when TEM transient conditions apply. This situation should be clarified in terms of ways to improve the voltage income through a natural cooling method. Figure 7 shows that the heatsink device type A is the best among the five because it produces the highest temperature gradient at each test temperature value. Type $\mathrm{C}$ also shows the same manner but at test temperature $100^{\circ} \mathrm{C}$ the temperature gradient value is lower than Type A heatsink. The performance of the heatsink is relates strongly to its thermal resistance value. From Table 3 it shows that 
Type A and Type C heatsink having only 4 and $7 \mathrm{C} / \mathrm{W}$ value of thermal resistance which is quite low compare to the other three heatsink types. These two heatsink type is characterized among the best heatsink according to its temperature gradient value. As mentioned, an TEM in a transient state is rarely discussed even without a heatsink; such an TEM mechanism is continuously discussed in this study, while considering other aspects that could increase the power generation of the TEM. The TEM merged with other energy harvesters and effective controllers to increase the power output during a transient TEM state is an example that requires further investigation.

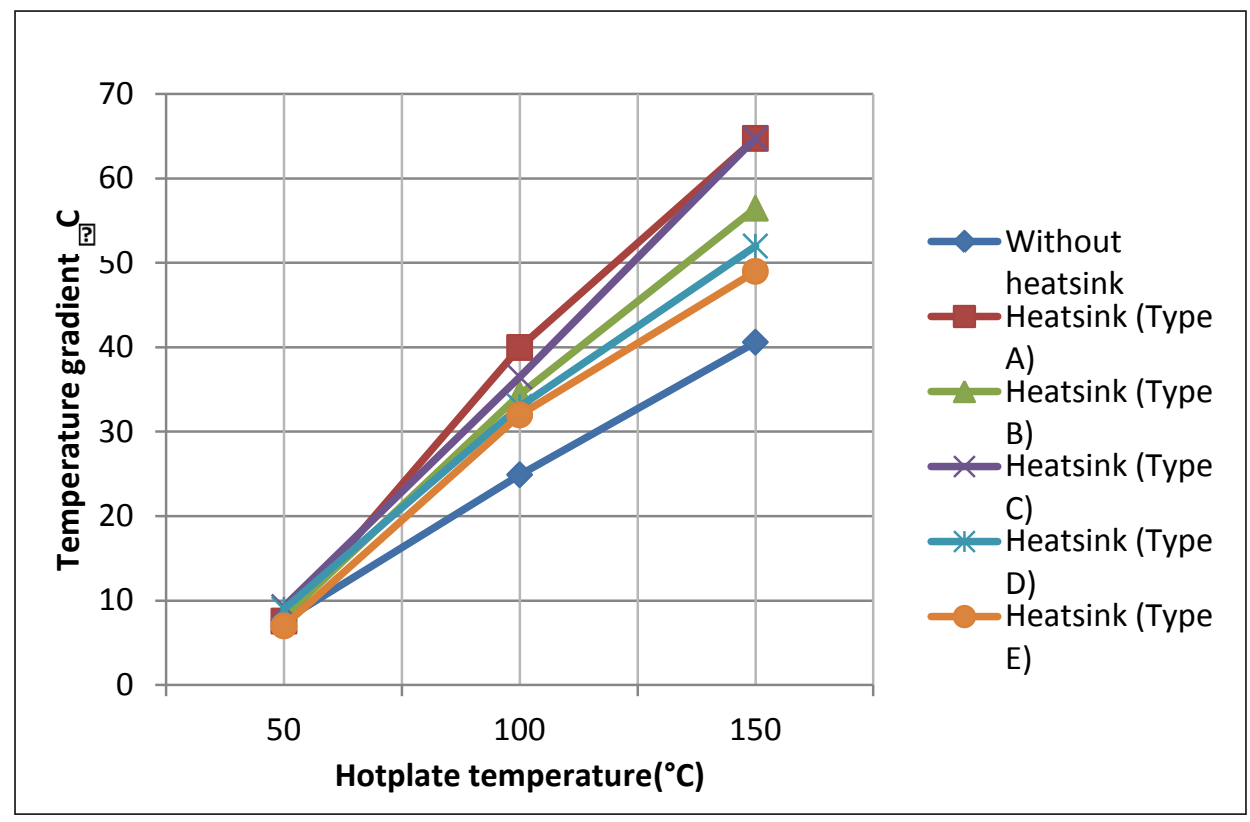

FIGURE 7. TEM temperature gradient for each heatsink configuration type compared with the TEM without a heatsink

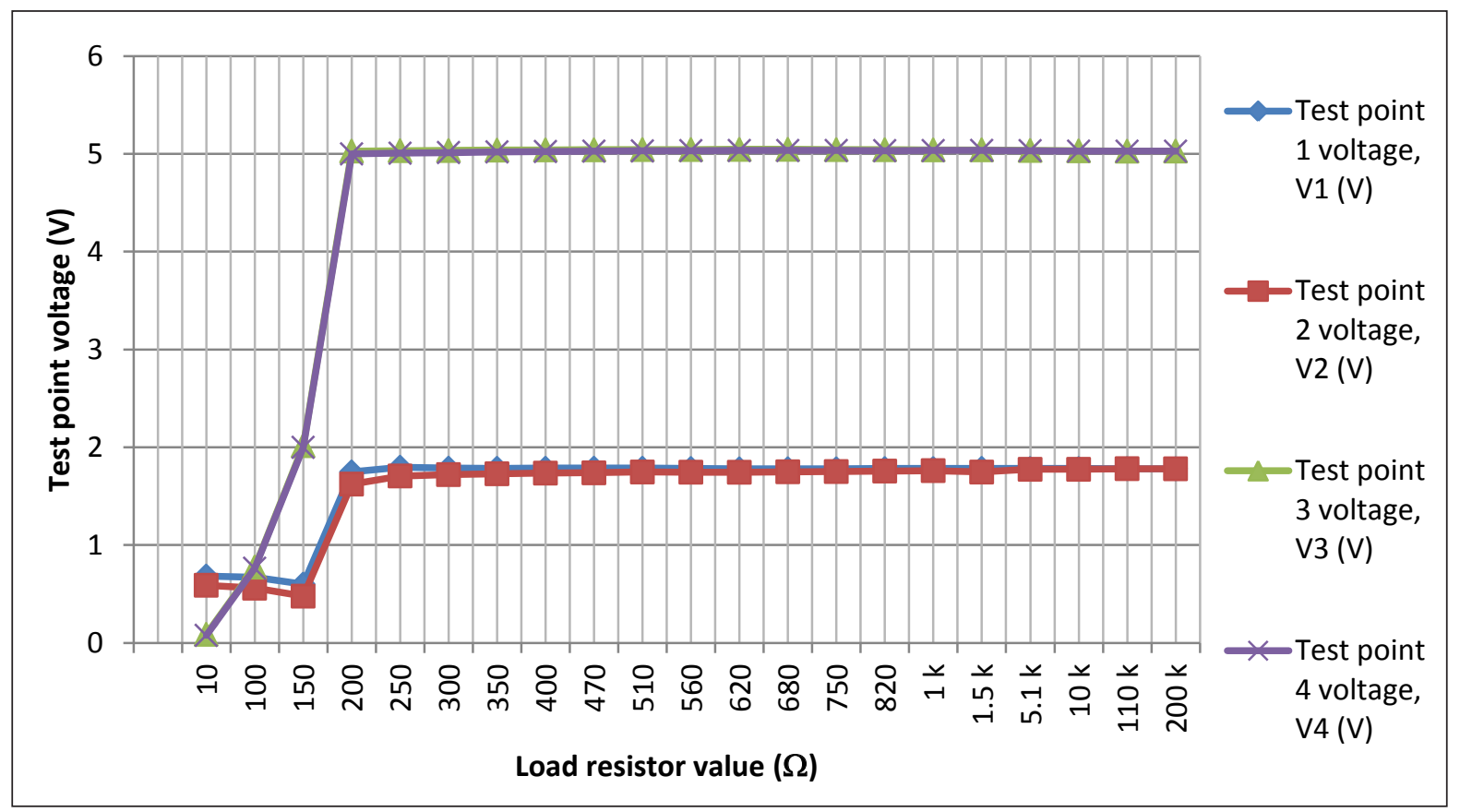

FIGURE 8. Voltage at each test point for different load resistor values 
In this part, several load resistor values are placed after the second MPPC board to configure the best range of load resistor value that could maintain system performance and enable the TEM to achieve maximum operational rating. The voltage values in all the test points labeled in Figure 1 are plotted in the same graph, as shown in Figure 8. The figure shows that the maximum rating value of $5 \mathrm{~V}$ of the load resistor voltage is attained at a load resistor of $200 \Omega$ onwards. A load resistor that is less than this value cannot obtain the $5 \mathrm{~V}$ voltage. This observation notably shows the limitations of this TEM system, in which the maximum rating of the system can be maintained only when the load resistor is $200 \Omega$ and above. This finding actually follows the voltage at test points 1 and 2 . When test point 1 and 2 voltages are achieved at approximately $1.7 \mathrm{~V}$, this system can improve the load resistor voltage by up to $5 \mathrm{~V}$. Thus, when the first MPPC board achieves around $1.7 \mathrm{~V}$, the energy from this board can be supplied to the second board together with a suitable load resistor value to obtain the maximum $5 \mathrm{~V}$ voltage. This energy will be used to charge a mobile phone in our next investigation. Given that mobile phones require a $5 \mathrm{~V}$ stable line voltage, this loading effect analysis is performed to obtain the best load resistor value that can make this TEM system work at the maximum point of the system.

\section{CONCLUSION}

In this study, TEM device behavior have been developed and tested. Four-part analysis has been performed, namely, temperature analysis of hot plate, TEM configuration, TEM configuration with a heatsink, and TEM loading effect. A correlation between TEM configuration and temperature gradients is found among the TEM junctions. When the hot side of the TEM junction is increased, a higher temperature gradient occurs and the TEM voltage is also increased. Given the same test temperature, the voltage generated also increases when the number of TEMs is increased. Using a heatsink in the system maintains the cold side of the TEM, which contributes to a larger temperature gradient. Given that the maximum rating of the MPPC board is $5 \mathrm{~V}$, a range of suitable load resistor values is connected in a closed circuit with an existing TEM system to obtain a suitable value that can enable the system to function optimally.

ACKNOWLEDGEMENTS

The authors would like to thank the Department of Electrical, Electronic and Systems Engineering, Faculty of Engineering and Built Environment, Universiti Kebangsaan Malaysia (UKM), the Universiti Teknikal Malaysia Melaka (UTeM), and the Ministry of Higher Education for moral, operational, and financial support for this project.
Aminov, P. \& Agrawal, J. P. 2014. Rf Energy Harvesting. 2014 IEEE 64th Electronic Components and Technology Conference (ECTC), hlm. 1838-1841.

Attia, P. 2014. Thermoelectric Power Generation in Dynamic Temperature Environments. Tesis. University of Delaware.

Bandyopadhyay, S. \& Chandrakasan, A. P. 2012. Platform architecture for solar, thermal, and vibration energy combining with mppt and single inductor. IEEE Journal of Solid-State Circuits 47(9): 2199-2215.

Bomberger, C. C., Attia, P. M., Prasad, A. K. \& Zide, J. M. O. 2013. Modeling passive power generation in a temporally-varying temperature environment via thermoelectrics. Applied Thermal Engineering 56(12): 152-158.

Bonin, R., Boero, D., Chiaberge, M. \& Tonoli, A. 2013. Design and characterization of small thermoelectric generators for environmental monitoring devices. Energy Conversion and Management 73(0): 340-349.

Carmo, J. P., Antunes, J., Silva, M. F., Ribeiro, J. F., Goncalves, L. M. \& Correia, J. H. 2011. Characterization of thermoelectric generators by measuring the load-dependence behavior. Measurement 44(10): 2194-2199.

He, W., Su, Y., Wang, Y. Q., Riffat, S. B. \& Ji, J. 2012. A study on incorporation of thermoelectric modules with evacuated-tube heat-pipe solar collectors. Renewable Energy 37(1): 142-149.

He, W., Zhou, J., Hou, J., Chen, C. \& Ji, J. 2013. Theoretical and experimental investigation on a thermoelectric cooling and heating system driven by solar. Applied Energy 107(0): 89-97.

Hong, C.-M. \& Chen, C.-H. 2014. Intelligent control of a grid-connected wind-photovoltaic hybrid power systems. International Journal of Electrical Power \& Energy Systems 55(0): 554-561.

Kim, S. 2013. Analysis and modeling of effective temperature differences and electrical parameters of thermoelectric generators. Applied Energy 102(0): 1458-1463.

Liao, T., Lin, B. \& Yang, Z. 2014. Performance characteristics of a low concentrated photovoltaicThermoelectric hybrid power generation device. International Journal of Thermal Sciences 77(0): 158-164.

Ma, M. \& Yu, J. 2014. An analysis on a two-stage cascade thermoelectric cooler for electronics cooling applications. International Journal of Refrigeration 38(0): 352-357.

Meng, J.-H., Wang, X.-D. \& Zhang, X.-X. 2013. Transient modeling and dynamic characteristics of thermoelectric cooler. Applied Energy 108(0): 340348. 
Merschmann, P. R. D. C., Vasquez, E., Szklo, A. S. \& Schaeffer, R. 2013. Modeling water use demands for thermoelectric power plants with ccs in selected Brazilian water basins. International Journal of Greenhouse Gas Control 13(87-101.

Nguyen, N. Q. \& Pochiraju, K. V. 2013. Behavior of thermoelectric generators exposed to transient heat sources. Applied Thermal Engineering 51(1-2): 1-9.

Rabari, R., Mahmud, S. \& Dutta, A. 2014. Numerical simulation of nanostructured thermoelectric generator considering surface to surrounding convection. International Communications in Heat and Mass Transfer 56(0): 146-151.

Rafiee, M., Siadatan, A., Afjei, E. \& Abadi, E. Z. A. 2012. Improving the Efficiency of Thermal Power Plant Using Thermoelectric Material. 2012 4th International Conference on Intelligent and Advanced Systems (ICIAS), hlm. 450-454.

Saadatfar, B., Fakhrai, R. \& Fransson, T. 2013. Waste heat recovery organic rankine cycles in sustainable energy conversion: A state-of-the-art review. J MacroTrends Energy Sustain 1(0): 161-188.

Stevens, R. J., Weinstein, S. J. \& Koppula, K. S. 2014. Theoretical limits of thermoelectric power generation from exhaust gases. Applied Energy 133(0): 80-88.

Tianpei, Z. \& Wei, S. 2014. Optimization of batterysupercapacitor hybrid energy storage station in wind/ solar generation system. IEEE Transactions on Sustainable Energy 5(2): 408-415.

Wang, X.-D., Wang, Q.-H. \& Xu, J.-L. 2013. Performance analysis of two-stage tecs (thermoelectric coolers) using a three-dimensional heat-electricity coupled model. Energy 65(0): 419-429.
Weng, C.-C. \& Huang, M.-J. 2014. A study of using a thermoelectric generator to harvest energy from a table lamp. Energy 76(0): 788-798.

Yusop, A., Mohamed, R., Ayob, A. \& Mohamed, A. 2014. Dynamic modeling and simulation of a thermoelectricsolar hybrid energy system using an inverse dynamic analysis input shaper. Modelling and Simulation in Engineering 0(0): 1-22.

Zhang, X.-R., Zhang, Y. \& Chen, L. 2014. Experimental study on solar thermal conversion based on supercritical natural convection. Renewable Energy 62(0): 610-618.

Ramizi Mohamed

Azdiana Md. Yusop*

Azah Mohamed

Nur Izzati Nordin

Department of Electrical, Electronic and Systems

Engineering,

Unversiti Kebangsaan Malaysia,

43600 UKM Bangi, Malaysia

Corresponding author; email: azdiana@utem.edu.my

Received date: $12^{\text {th }}$ November 2015

Accepted date: $28^{\text {th }}$ March 2016 